\title{
A Different Type of Micro-Perforate Hymen: Micro Three- Hole Hymen
}

\author{
Farklı Bir Mikro Delikli Hymen: Mikro Üç Delikli Hymen
}

\author{
(1) Mahmut Aşırdizer, Prof. MD.1, (1) Gizem Demet Sever, MD.2, (1) İsmail Oymak, MD.2, (1) İsmail Tilki, MD.2 \\ 1Bahçeşehir University Faculty of Medicine, Department of Forensic Medicine, İstanbul, Turkey \\ 2 Van Yüzüncü Yıl University Faculty of Medicine, Department of Forensic Medicine, Van, Turkey
}

\section{ABSTRACT}

Developmental abnormalities of hymen occur as a result of failures in breaking or rupturing the genital tubercle within embryological phase. Cribriform hymen, septal hymen, anterior displaced hymen, imperforate hymen and rigid or elastic hymen are variations of the embryologic development of the hymen. Also, microperforate hymen is defined as a different type of imperforate hymen which has a small opening. In this article, we reported a different type of microperforate hymen, which was reported limitedly in the literature. A 17-year-old female case applied forensic medicine polyclinic for sexual abuse examination at the request of the prosecutor. Any traumatic lesion was not seen in the extragenital and genital examination. At first glance, hymen looked like an imperforate hymen. When it was carefully investigated and consulted to gynecology and obstetrics specialist, three crescent-shaped holes were seen on it. This was evaluated as a previously unspecified type in the literature of microperforate hymen.

Keywords: Hymen types, hymen abnormalities, microperforate hymen, sexual abuse

\section{ÖZ}

Hymen gelişim anormallikleri, embriyolojik fazda genital tüberkülün kırılması veya yırtılmasındaki başarııızlıkların bir sonucu olarak ortaya çıkar. Kalburumsu hymen, septalı hymen, öne yer değiştirmiş hymen, deliksiz hymen ve sert veya elastik hymen, hymenin embriyolojik gelişiminin varyasyonlarıdır. Keza mikro delikli hymen, küçük bir açıklığa sahip deliksiz hymen in değişik bir tipi olarak tanımlanmıșır. Bu makalede literatürde sınırlı sayıda bildirilmiş olan mikro delikli hymenin farklı bir tipi tanımlanmışıı. On yedi yaşındaki kadın hasta, savcının talebi üzerine adli tıp polikliniğine cinsel istismar muayenesi için başvurdu. Ekstra genital ve genital muayenede travmatik lezyon görülmedi. Illk bakışta hymen, deliksiz bir hymen gibi görünüyordu. Dikkatle araștııılığında ve kadın hastalıkları ve doğum uzmanına danışıldığında, üzerinde üç hilal şeklinde delik görüldü. Bu, mikrodelikli hymenin literatürde daha önce belirtilmemiş değişik bir tipi olarak değerlendirildi.

Anahtar Kelimeler: Hymen türleri, hymen anomalileri, mikro delikli hymen, cinsel istismar

\section{INTRODUCTION}

Hymen is a mucosal membrane that partially closes orifice of the vagina. The name of this membrane is defined as hymen, because Hymenaios or Hymenaeus, in Helennistic religion, was the name of the songs sung on the wedding day and was a god whom the hymen is dedicated to him on the first night of sexual intercourse following wedding $(1,2)$. Hymen has attracted the attention of mankind throughout history, although there is only a fold of mucous membranes. Even today, it is accepted as a sign of virginity, and the cause of humiliation and murders of women in some societies, although an outdated belief in many societies (3).

Currently, it is located within the area of interest of anatomy, pediatrics, gynecology and forensic medicine specialists $(4,5)$. 
Physical findings of sexual abuse can be seen on multiple areas of the genital and/or other body regions. In sexual assault examinations, focusing only on hymen is one of the biggest mistakes that can be made, even if it has been recognized as one of the most important indicators of vaginal rape in the past $(1,2)$.

Hymen typings have differences according to many clinical and forensic medicine studies. The broadest definition of hymen typing prepared using different literature is presented in Table 1.

Cribriform hymen, septal hymen, anterior displaced hymen, imperforate hymen and rigid or elastic hymen are variations of the embryologic development of the hymen (6). Also microperforate hymen is defined as different type of imperforate hymen which has a small opening. It can causes negative effects in the vaginal intercourse and menstrual hygiene, and negatively impacts the quality of life of the adolescence $(7,8)$.

The incidence of imperforate hymen is from $0.014 \%$ to $0.1 \%$ of the female newborns (7). The number of literature about microperforate hymen is very limited (8). In August 2019, these numbers in the database are 12 in PubMed, 13 in Scopus and 8 in Web of Science. All of these microperforated hymen have two holes and none of them have three holes defined.

In this article, we reported a different type of microperforate hymen had three micro openings on its. In addition, we mentioned the duties of forensic medicine specialists because of this case report.

\section{CASE REPORT}

A 17-year-old female case was applied forensic medicine polyclinic for sexual abuse examination at the request of the prosecutor. According to story of the victim, "she was single and had no sexual experience, and she has regular menstrual period. Two weeks ago, she went for a trip together a 45-yearold male neighbor with his automobile. The accused has contacted with her vagina by his tongue, except prompt of her. During the incident, the victim and the accused were under the influence of alcohol. Therefore, the victim had unable to resist to behavior of the accused. The accused had not attempted vaginal or anal penetration".

Any traumatic lesion was not seen in the extra-genital examination. In the genital examination, there was no vulvar, vaginal and anal traumatic lesion. Hymen seemed to be imperforated. When it was carefully investigated, there were three crescent-shaped holes on it (Figure 1). The specialist of gynecology and obstetrics confirmed the hymen type, too. No biological sample was taken due to presence the twoweek period between sexual abuse and medical examination and to bathing of victim after the event. The medical-legal report on the lack of medical evidence of sexual abuse and the need to clarify the case by forensic investigation was sent to the prosecutor. Furthermore, the victim was referred to

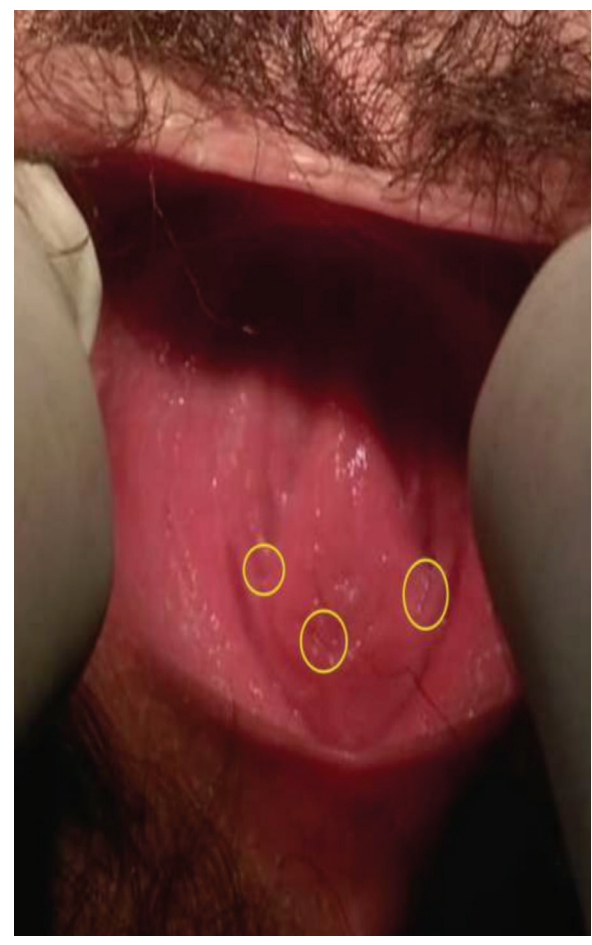

Figure 1. Micro three-hole hymen

\begin{tabular}{|l|l|l|l|l|l|}
\hline \multicolumn{2}{|l|}{ Table 1. The broadest definition of hymen typing prepared using different literature } \\
\hline According to the appearance of the hymen hole & $\begin{array}{l}\text { According to the } \\
\text { appearance of the } \\
\text { hymen free edge }\end{array}$ & $\begin{array}{l}\text { According to the } \\
\text { resistance of the } \\
\text { hymen }\end{array}$ & $\begin{array}{l}\text { According to the } \\
\text { elasticity of the } \\
\text { hymen }\end{array}$ & $\begin{array}{l}\text { According to the } \\
\text { size of the hymen } \\
\text { hole }\end{array}$ \\
\hline Typical & Atypical & $\begin{array}{l}\text { Cribriform } \\
\text { (Sieve-like) }\end{array}$ & Thin & Elastic & Large hole \\
\hline $\begin{array}{l}\text { Annular } \\
\text { Labial (Navicular, boat- } \text { Sleeve-like) }\end{array}$ & Imperforate & Fimbriated & Tendinous & Rigid & Small hole \\
\hline Crescentic (Semilunar) & Micro-perforate (Pinhole) & Dentate (Denticulare) & Gristly & - & - \\
\hline Sickle-like1 & $\begin{array}{l}\text { Septate Hymen } \\
\text { (Bifenetratus or trifenetratus) }\end{array}$ & Lobe & - & - & - \\
\hline- & $\begin{array}{l}\text { Languette hymen (tongue- } \\
\text { Shaped hymen) }\end{array}$ & Redundant & - & - \\
\hline${ }^{1}$ Crescentic shape, which prolonged upwards with two ends. & & & - \\
\hline
\end{tabular}


the gynecology and obstetrics polyclinic after explaining the sexual and medical problems she might have. She was referred to another hospital for psychiatric support, as she was not a child psychiatry specialist at our hospital on the specified date.

\section{DISCUSSION}

There are four stages of Mullerian development in embryonic life, hymen development occurs after internal canalization and septal resorption following $20^{\text {th }}$ gestational week and hymen hole occurs by birth $(8,9)$. Developmental abnormalities of hymen occur as a result of failures in breaking or rupturing the genital tubercle within these stages $(8,10)$.

Microperforated hymen which is seen on thin hymen is one of these anomalies and is not stop menstrual blood to flow out completely. Microhole on the hymen is permeable for menstrual blood and sperms. However, it can cause slow, painful and difficult menstruation $(10,11)$.

The patient may complain about vaginismus and unsuccessful intercourse, or even inability touse the tampon, vaginal creams or suppositories $(7,11)$.

Recurrent vulvovaginitis, urinary tract infections, ascending pelvic infections are common complications in girls with microperforated hymen before puberty $(7,10,11)$. The accumulation of urine in the functional urogenital sinus and its entry into the urinary tract is the most important cause of recurrent urinary tract infections (10).

Likewise, in cases where the hole in the hymen is small and cannot discharge the accumulated menstruation blood, primary amenorrhea, cyclic pelvic pain, symptoms due to compression of the bladder or intestine, hematocolpos, hydrometrocolpos, hematometra and hematosalpinx are other expected complications (7).

Early diagnosis of microperforate hymen will improve the quality of life of girls and prevent complications that women may experience in their adult ages (11).

The primary duty of the forensic expert is to prepare a report on this matter as a basis for criminal proceedings in the case of sexual abuse and sexual assault. The prevention of unwanted pregnancies, the prevention of sexually transmitted diseases, the supplying contact with social institutions and psychiatry services to which they can receive support, and the informing them about the issues that may pose a risk to their health are other duties of them (12).

Sexual assault examinations are not only about genital and extragenital examinations, multidisciplinary approach with a team of experts from different branches in private centers structured for sexual assault will prevent exposure to mental and physical trauma of the victim by being examined repeatedly (13).

In the present case, it could not be denied that the person had been subjected to sexual abuse, although the medical evidence of sexual abuse was not established. Article 103 of the Turkish Penal Code, which regulates sexual abuse, includes not only completed penetrations, but also crimes such as molestation and attempted sexual assault. Specifically for this case, in case of the occurrence of molestation and attempted sexual assault, biological samples that can be found in the automobile, surveillance camera records that can see the scene, possible witness statements, and the stains and materials that can be detected on the accused and his clothes at the time of the event are other evidences that can be used in the analysis of the incident.

During the examination of the victim in the forensic medicine clinic, a different type of microperforated hymen was observed, indicating that there was no complete vaginal perforation during sexual activation. Although the victim did not have any menstrual disorders, and did not define vaginismus and unsuccessful intercourse due to lack of previous sexual experience; she was referred to the obstetrics and gynecology outpatient clinic by taking into consideration sexual and medical problems such as unwanted pregnancy, sexually transmitted diseases and difficulty in sexual intercourse in advanced life. She was referred to another hospital for psychiatric support, as she was not a child psychiatry specialist at our hospital on the specified date.

\section{CONCLUSION}

In the literature, the number of articles related to microperforated hymen is very limited and their number does not exceed 12 in PubMed, 13 in Scopus and 8 in Web of Science. In this case report, micro three-hole hymen was reported as different type of microperforate hymen. Additionally, the complications related to this hymen, and unlike other articles, the secondary tasks associated with preventive medicine services of forensic specialists were briefly explained.

\section{ETHICS}

Ethics Committee Approval: Our study was written on the case, in accordance with the Declaration of Helsinki, and ethical permission was not required.

Peer-review: Internally peer-reviewed.

\section{Authorship Contributions}

Surgical and Medical Practices: M.A., G.D.S., I.O., I.T., Concept: M.A., G.D.S., Design: M.A., I.O., I.T., Data Collection or Processing: G.D.S., I.O., Analysis or Interpretation: M.A., I.T., Literature Search: I.O., I.T., Writing: M.A., G.D.S.

Conflict of Interest: No conflict of interest was declared by the authors.

Financial Disclosure: The authors declared that this study received no financial support. 


\section{REFERENCES}

1. Akkay E. The problems of virginity in marriages in Turkey. İstanbul Üniversitesi Hukuk Fakültesi Mecmuası. 1983;48(1-4):325-333.

2. Stewart ST. Hymenal Characteristics in girls with and without a history of sexual abuse. J Child Sex Abus. 2011;20(5):521-536

3. Hegazy AA, Al-Rukban MO. Hymen: facts and conceptions. Health. 2012;3(4):109-115.

4. Onderoğlu S, Aksit D, Onderoğlu LS. The configuration of prepubertal hymen in turkish population and its clinical aspect. Okajimas Folia Anat Jpn. 1993;70(1):35-39.

5. Eg MB, Hansen LA, Sabroe S, Charles AV. Hymenal lesions and legal outcome in sexually abused girls with a history of vaginal penetration. Forensic Sci Int. 2015;252:163-167.

6. Elgyoum AMA, Mohammed EAE, Mohammed AA. Case report diagnosing of imperforate hymen by ultrasound. Int J Biomed Mater Res. 2016;4(3):27-30
7. Ferrarini OMF, Munhoz LO, Simões RS, Cezarino PYA, Mieli MPÂ, Margarido PFR, et al. Microperforated hymen: a case of delayed diagnosis. Autops Case Rep. 2014;4(3):59-63.

8. Watrowski R, Jäger C, Gerber M, Klein C. Hymenal anomalies in twins--review of the literature and case report. Eur J Pediatr. 2014;173(11):1407-1412.

9. Burgis J. Obstructive müllerian anomalies: case report, diagnosis, and management. Am J Obstet Gynecol. 2001;185(2):338-344.

10. Güven D, Bakay K, Kuruoglu S. Microperforate (pinhole) hymen and infertility: a rare case report. Open J Obstet Gynecol. 2012;2(3):287-288.

11. Kumar V, Kumar KV, Krishnamurthy KH, Kumar R. A rare case report of microperforate hymen with difficulty in penetration. J SAFOMS. 2014;2(2):9798.

12. Sozen S, Aksoy E. Physician responsibility, and medical and legal approach in sexual assaults (Turkish). Klinik Gelisim. 2009;22:101-109.

13. Canturk G, Canturk N. Examination procedure of sexual assault victims. Turkiye Klinikleri J Surg Med Sci. 2006;2(50):49-55 